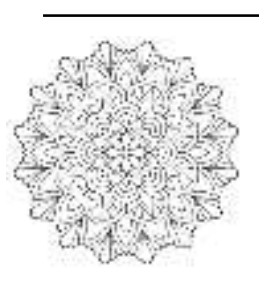

AL HIKMAH: INDONESIAN JOURNAL OF EARLY CHILDHOOD ISLAMIC EDUCATION

ISSN (P): 2550-2200, ISSN (E): 2550-1100,

VOL. 4 (1), 2020, PP. $40-51$

http://journal.iaialhikmahtuban.ac.id/index.php/ijecie

\title{
PERAN ORANG TUA DALAM MENINGKATKAN PERILAKU BERBICARA SANTUN ANAK USIA DINI DI RT 04/RW 02 DESA KAJEN MARGOYOSO PATI
}

\author{
Sumiyati \\ Prodi Pendidikan Islam Anak Usia Dini, Institut Pesantren Mathali'ul Falah Pati \\ atikpaudi@gmail.com \\ Penelitian ini adalah penelitian kualitatif yaitu penelitian lapangan, peneliti mendeskripsikan \\ temuan-temuan yang bersumber dari lapangan. Data penelitian didapatkan dari hasil wawancara \\ dengan responden, yang terdiri dari orang tua, dan tokoh masyarakat serta observasi terhadap \\ anak-anak di Desa Kajen Rt 04 / Rw 02. Teknik pengumpulan data yang digunakan adalah melalui \\ hasil observasi, wawancara, dan dokumentasi. Sedangkan analisis teknis data meliputi reduksi \\ data, penyajian data, serta verifikasi. Dari hasil penelitian ini menunjukkan bahwa peran orang tua \\ di Rt 04 / Rw 02 Desa Kajen Margoyoso Kabupaten Pati terkait dalam Meningkatkan Perilaku \\ Berbicara Anak Usia Dini sebagian besar baik, lancar dan berkembang sesuai dengan \\ perkembangan usianya. Hanya saja mereka sebagai orang tua perlu tahu dan sadar bahwa, \\ mendidik anak harus dengan kesabaran dan ketekunan. Orang tua dapat mengajarkan perilaku \\ berbicara sopan dengan membiasakan anak-anak dengan hal-hal yang terpuji sejak usia dini. \\ Karena anak-anak adalah cerminan dari tindakan orang tua mereka. Sehingga harapan orang tua \\ nantinya anak-anak dapat berperilaku dan berbicara sopan dengan semua orang.
}

Kata Kunci : Peran Orang Tua, Perilaku Berbicara Santun

\section{Abstract}

This research is a qualitative research that is field research, researchers describe the findings sourced from the field. The research data were obtained from interviews with respondents, consisting of parents and community leaders as well as observations of children in Kajen Village Rt 04 / Rw 02. Data collection techniques used were through observation, interviews, and documentation. While the technical analysis ofdata includes data reduction, data presentation and verification. From the results of this study indicate that the role of parents in Rt $04 / R w 02 \mathrm{Kajen}$ Margoyoso Village Pati Regency related in Improving Early Childhood Speaking Behavior is mostly good, smooth and develops according to the development of his age. It's just that they as parents need to know and be aware that, educating children must be with patience and perseverance. Parents can teach polite speaking behavior by familiarizing children with things that are praiseworthy from an early age. Because children are a reflection of the actions of their parents. So that the hope of parents later children can behave and talk politely with everyone.

Keywords: Role of Parents, Courteous Speaking Behavior 


\section{PENDAHULUAN}

Pendidikan pra sekolah merupakan tingkatan pendidikan sebelum jenjang pendidikan dasar yang berupa suatu usaha pembinaan yang diperuntukkan bagi seorang anak semenjak lahir sampai pada usia enam tahun yang dilaksanakan dengan memberikan stimulasi pendidikan untuk membantu pertumbuhan dan perkembangan jasmani dan rohani agar anak memiliki kesiapan dalam memasuki pendidikan lebih lanjut yang diselenggarakan pada jalur baik formal, jalur nonformal, maupun informal (Lilis M, 2016).

Orang tua memiliki peran untuk bertanggung jawab atas pemeliharaan dan kebutuhan pendidikan anak (Jane Brooks, 2011). Tanggungjawab orang tua tidak sebatas sebagai pemimpin dalam sebuah keluarga. Akan tetapi lebih jauh dari itu, Orangtua dituntut untuk mempunyai kemampuan dalam menumbuh kembangkan potensi-potensi yang dimiliki oleh anak. Oleh karena itu, orang tua harus mau membuka diri untuk belajar memahami dunia anak dengan segala kerumitannya. Memang ini bukan pekerjaan yang mudah, karena orang tua diharapkan dapat mengerti betul tentang persoalan-persoalan anak. Kemampuan orang tua dalam menempatkan dirinya tentu saja menjadi modal besar untuk membuat langkah yang semakin maju dan luas dalam mendampingi anak (E.Widijo, 2017).

Dalam Bahasa Jawa ada pepatah, kacang mangsa tinggal lanjaran. Identik dengan pribahasa bahasa Indonesia, air cucuran atap jatuhnya kepelimbahan juga. Artinya, perilaku atau tindakan anak tidak jauh menyimpang dari kebiasaan orang tuanya bertindak. Tidak salah apabila orang tua diperlakukan sebagai guru pertama sebelum mengenal guru di sekolah. Oleh karenanya baik dan buruknya perilaku anak diluar rumah, sering membawabawa nama dan citra orang tuanya. Masyarakat telah mengambil asumsi bahwa anak merupakan cerminan orang tua (Marijan, 2012).

Pemilihan bahasa yang tepat akan mengantarkan komunikasi yang baik, sehingga pesan yang dimaksud dapat tersampaikan. Perilaku yang tepat juga akan mendukung ketepatan informasi yang disampaikan karena perilaku merupakan bahasa tubuh yang mendukung bahasa lisan. Karakter santun yang dimiliki oleh anak usia Sekolah Dasar (SD) dapat diwujudkan dengan menggunakan bahasa yang tepat ketika berbicara baik dengan orang yang lebih tua, dengan sesama kawan, ataupun dengan yang lebih muda. Suara yang digunakan ketika berbicara tidak terlalu keras, tetapi jelas. Begitu pula dengan perilaku, kepada yang lebih tua menghormati, sesama kawan dan yang lebih muda menyayangi.

Berdasarkan uraian di atas, dapat diketahui bahwa karakter santun erat hubungannya dengan kehalusan bahasa dan perilaku yang ditunjukkan kepada semua orang, baik kepada 
yang lebih tua, seumuran, maupun kepada yang lebih muda. Karakter santun dapat mempererat hubungan antara manusia dengan sesamanya, sehingga akan dapat menjaga persatuan dan kesatuan (Atikah M., 2013).

Perilaku sosial pada anak usia dini ini diarahkan untuk pengembangan sosial yang baik, seperti kerja sama, tolong menolong, berbagi, simpati, empati, dan saling membutuhkan satu sama lain (Ahmad Susanto, 2017). Dengan demikian, dapat disimpulkan dengan jelas bahwa perilaku sosial adalah segala bentuk tindakan yang dilakukan dengan sikap peduli dan mau membantu sesama dengan sukarela tanpa timbal balik.

Menurut Rose Mini A. Prianto, dkk, 2013, secara spesifik, beberapa pola perilaku sosial pada anak usia dini antara lain:

1. Kerja Sama, bermain dan beraktivitas, berusaha memberi peluang agar anak dapat bekerja sama dan saling menghargai.

2. Persaingan, persaingan dengan sahabat akan menumbuhkan dorongan/ motivasi untuk bekerja sama dengan baik. Bukan mengekpresikan persaingan dalam bentuk pertengkaran atau kesombongan.

3. Kemurahan hati, kesediaan bekerja sama dan bermain bersama, meningkatkan kemurahan hati dan jiwa besar, menjauhkan sikap hanya memikirkan kepentingan pribadi.

4. Simpati, anak belajar berperilaku simpati dan mengekpresikannya dalam usaha menolong sahabat secara empati.

5. Empati, belajar memposisikan diri anak dalam posisi orang lain atau sahabat dan belajar memahami penghayatan orang lain.

6. Ramah, melalui interaksi sosial, anak belajar mengapresiasikan kasih sayangnya kepada orang lain dengan ramah.

Perilaku emosional ialah suatu hal yang terorganisasi dan muncul terhadap hal-hal yang berhubungan dengan kebutuhan, tujuan, ketertarikan, dan minat individu. Ciri dari perilaku emosional anak ialah reaksi yang kuat dan spontan terhadap situasi yang menimbulkan rasa senang atau tidak senang. Anak akan mengutarakan perasaan, keadaan, dan informasi yang mereka terima apa adanya, tidak ditutup-tutupi (Ahmad Susanto, 2017).

\section{A. Berbicara}

Penguasaan bahasa sebagai alat komunikasi adalah salah satu pencapaian yang besar dalam proses perkembangan anak (Ratna Wulan, 2011). Bicara merupakan keterampilan, dan seperti halnya semua keterampilan, ia harus dipelajari. Bicara terdiri atas kemampuan 
mengeluarkan bunyi tertentu dalam kombinasi yang dikenal sebagai kata yaitu aspek motorik bicara, dan kemampuan mengaitkan arti dengan kata-kata yaitu aspek mental dari bicara.

1. Aspek Berbicara

Secara garis besar ada dua faktor yang dapat dijadikan indikator, untuk mengukur kemampuan berbicara seseorang yakni aspek kebahasaan dan non kebahasaan.

A. Aspek kebahasaan meliputi: ketepatan pengucapan, penempatan tekanan, nada, sendi, durasi, yang sesuai pilihan kata, dan ketepatan sasaran pembicaraan.

B. Aspek non kebahasaan meliputi: sikap tubuh, pandangan, bahasa tubuh, dan mimik yang tepat, kesediaan menghargai pembicaraan maupun gagasan orang lain, kenyaringan suara dan kelancaran dalam pembicaraan dan relevansi, penalaran, dan penguasaan topik tertentu.

Menurut pendapat Hurlock dalam M. Usman (2012) menjelaskan bahwa dalam belajar berbicara terdapat 3 aspek terpisah tetapi saling berhubungan satu sama lain:

a. Belajar mengucapkan kata

b. Membangun kata-kata

c. Membentuk kalimat

2. Teori Perkembangan Bahasa Anak usia Dini

Bahasa merupakan landasan seorang anak untuk mempelajari hal-hal lain. Sebelum dia belajar pengetahuan-pengetahuan lain, dia perlu menggunakan bahasa agar dapat memahami dengan baik. Teori-teori yang digunakan untuk pengembangan bahasa bagi anak usia dini (Alfitriani Siregar, 2018) adalah:

a. Teori Behaviorist dari Skinner

Teori ini mendefinisikan pembelajaran dipengaruhi oleh perilaku. Para behaviorist mempercayai bahwa manusia dibentuk oleh lingkungan eksternalnya. Jadi kita perlu mengubah lingkungan pembelajaran agar dapat mempengaruhi pikiran, perasaan, dan perilaku anak secara bertahap. Perilaku yang positif jika diperkuat cenderung untuk diulangi lagi, karena pemberian penguatan secara berkala dan disesuaikan dengan kemampuan anak akan efektif untuk membentuk perilaku anak.

Aktivitas pemerolehan bahasa yang mengimplementasikan teori behavioristist pendidikan perlu memberikan penguatan dalam bentuk pujian atau hadiah terhadap bicara anak walaupun belum lancar atau jelas pengucapannya. 


\section{b. Teori Nativist dari Chomsky}

Teori Nativist mengutarakan bahwa bahasa sudah ada di dalam diri anak. Pada saat seorang anak lahir, dia telah memiliki seperangkat kemampuan berbahasa yang disebut "Tata Bahasa Umum" atau "Universal Grammer". Teori ini mengatakan bahwa meskipun pengetahuan yang ada di dalam diri anak tidak mendapatkan banyak rangsangan, anak akan tetap dapat mempelajarinya. Anak tidak sekedar meniru bahasa yang dia dengarkan, tapi ia juga mampu menarik kesimpulan dari pola yang ada, hal ini karena anak memiliki sistem bahasa yang disebut perangkat Penguasaan Bahasa.

\section{c. Teori Constructive}

Perkembangan kognisi dan bahasa dibentuk dari interaksi dengan orang lain. Dengan berinteraksi dengan orang lain, maka pengetahuan, nilai sikap anak akan berkembang. Anak memiliki perkembangan kognisi yang terbatas pada usia-usia tertentu, tetapi melalui interaksi social, anak akan mengalami peningkatan kemampuan berpikir.

3. Tahapan Perkembangan Bahasa Anak Usia Dina

Secara umum tahapan-tahapan perkembangan anak dapat dibagi kedalam beberapa rentang usia, yang masing-masing menunjukkan ciri-ciri tersendiri. Menurut Guntur (1988), tahapan perkembangan ini sebagai berikut:

a. Tahap III (pengembangan tata bahasa, yaitu prasekolah 3,4,5 tahun). Pada tahap ini anak sudah dapat membuat kalimat, seperti telegram. Dilihat dari aspek pengembangan tata bahasa seperti: S-P-O, anak dapat memperpanjang kata menjadi satu kalimat.

b. Tahap IV (tata bahasa menjelang dewasa, yaitu 6-8 tahun). Tahap ini ditandai dengan kemampuan yang mampu menggabungkan kalimat sederhana dan kalimat kompleks.

\section{B. Santun}

Sopan santun berbahasa dapat dijadikan tolok ukur seseorang. Orang dapat dihargai dan dihormati orang lain melalui bahasa yang diucapkannya. Orang juga bisa dihina, direndahkan, dan tidak dihargai juga karena bahasa yang dia ucapkan. Padahal pada dasarnya semua orang ingin dihargai. Maka dari itu, mereka taat pada sopan santun berbahasa (Budi Artati, 2009).

Pengertian sopan santun menurut Abdul Muhammad Nur Hafizh dalam Sukini (2016) menyatakan sopan santun adalah suatu etika atau norma terhadap tingkah laku kita dalam kehidupan sehari-hari. 
1. Sopan Santun Dalam Kehidupan Sehari-hari
a. Menghormati orang yang lebih tua
b. Tidak berkata-kata kotor, kasar, dan sombong
c. Tidak meludah disembarang tempat
d. Menerima sesuatu selalu dengan tangan kanan
e. Memakai pakaian yang dapat menutup aurat
f. Tidak menyela pembicaraan

\section{Manfaat Sopan Santun}

Bagi diri sendiri yaitu:
a. Dapat dihargai, dihormati, dan disenangi oleh banyak orang
b. Dapat memupuk rasa persaudaraan, pertemanan, serta persahabatan
c. Mendapat kepercayaan dari orang lain
d. Dapat menghindari dari perselisihan, pertentangan, dan permusuhan dengan orang lain
e. Menjaga hubungan baik dan harmonis dengan orang yang berada disekitar kita
Bagi orang lain yaitu:
a. Akan merasa dihargai dan dihormati oleh orang lain
b. Memupuk rasa persahabatan dan persaudaraan
c. Dapat membina dan menjaga hubungan baik
d. Dapat meringankan bebannya apabila sering diberikan pertolongan dari orang lain.

\section{Anak Usia Dini}

Pendidikan Anak Usia Dini (PAUD) pada hakikatnya ialah pendidikan yang diselenggarakan dengan tujuan untuk memfasilitasi pertumbuhan dan perkembangan anak secara menyeluruh atau menekankan pada pengembangan seluruh aspek kepribadian anak (Suyadi, dkk, 2013). Sebagaimana tercantum dalam Undang-Undang RI No. 20 Tahun 2003 bahwasannya Pendidikan Anak Usia Dini (PAUD) adalah suatu upaya pembinaan yang ditujukan kepada anak sejak lahir sampai dengan usia 6 tahun yang dilakukan melalui pemberian rangsangan pendidikan, untuk membantu pertumbuhan dan perkembangan jasmani dan rohani agar anak memiliki kesiapan dalam memasuki pendidikan lebih lanjut (Sumiyati, 2014).

Tujuan pendidikan Anak Usia Dini menurut Suyanto yang menyatakan bahwa tujuan PAUD adalah untuk mengembangkan seluruh potensi anak (the whole child) agar kelak dapat 
berfungsi sebagai manusia yang utuh sesuai falsafah suatu bangsa. Menurut Sumiyati (2014) tujuan Pendidikan Anak Usia Dini adalah sebagai berikut:

1. Kesiapan anak memasuki pendidikan lebih lanjut

2. Mengurangi angka mengulang kelas

3. Mengurangi angka putus sekolah

4. Mempercepat pencapaian wajib belajar pendidikan dasar 9 tahun

5. Menyelamatkan anak dari kelalaian didikan wanita karier dan ibu pendidikan rendah

6. meningkatkan mutu pendidikan

7. Mengurangi angka buta huruf muda

8. Memperbaiki derajat kesehatan dan gizi anak usia dini

9. Meningkatkan indeks pembangunan manusia (IPM).

\section{METODE}

Jenis Penelitian ini menggunakan JenisField Researc atau penelitian lapangan. Penelitian lapangan (field Researc)yaitu peneliti terjun langsung ke lapangan (ke obyek penelitian) (Suharsimi A., 1998). Dengan mengambil latar belakang dari Desa Kajen Rt 04 Rw 02 Margoyoso Pati. Jenis penelitian ini termasuk jenis penelitian kualitatif.

Sedangkan sifat penelitiannya termasuk penelitian deskriptif yaitu penelitian yang berusaha untuk mendeskripsikan suatu gejala, peristiwa, maupun kejadian yang terjadi sekarang. Penelitian deskriptif memusatkan perhatian kepada masalah-masalah aktual sebagaimana adanya pada saat penelitian berlangsung (Widya Iswara, dkk, 2008).

Sumber data dalam pengumpulan data menggunakan data primer dan data sekunder. Data Primer adalah sumber informasi yang secara langsung berkaitan dengan tema yang menjadi pokok pembahasan (Sugiyono, 2009). Dalam penelitian ini data yang diperoleh dari responden terhadap rangkaian pertanyaan digunakan oleh peneliti. Responden tersebut adalah orangtua dari anak usia dini di Desa Kajen Rt04 Rw02 Kecamatan Margoyoso Kabupaten Pati.

Sedangkan data sekunder adalah data yang diperoleh dari pihak lain, tidak langsung diperoleh dari subyek penelitiannya (Sugiyono, 2009). Data sekunder dari penelitian ini berupa data-data profil desa, jumlah penduduk, jumlah kepala keluarga dan jumlah anak usia 
dini yang ada di Desa Rt04 Rw02 Margoyoso pati dan data-data lainnya yang dipandang relevan serta mendukung penelitian ini.

Teknik pengumpulan data yang peneliti gunakan adalah observasi, wawancara, dokumentasi. Instrumen dalam penelitian kualitatif adalah peneliti sendirri. Sebagai Instrumen penelitian, peneliti berfungsi untuk menetapkan fokus penelitian, memilih informan sebagai sumber data, melakukan pengumpulan data, analisis data dan membuat kesimpulan atas semuanya (Sugiyono, 2009).

Sedangkan teknik analisis data dalam penelitian kualitatif, dilakukan sebelum ke lapangan, dan selama di lapangan.

a. Analisis sebelum dilapangan

Analisis sebelum peneliti memasuki lapangan meliputi analisis terhadap data hasil studi pendahuluan atau data sekunder yang akan digunakan untuk menentukan fokus penelitian yang akan dirumuskan. Namun demikian, fokus penelitian ini masih bersifat sementara, dan akan berkembang setelah peneliti masuk dan selama dilapangan (Sugiyono, 2009).

b. Analisis selama dilapangan

Analisis yang peneliti lakukan selama dilapangan adalah data reduktion (reduksi data), data display (penyajian data), conclusion drawing/verification (penarikan kesimpulan dan ferifikasi) (Sugiyono, 2009).

\section{HASIL DAN PEMBAHASAN}

\section{Perkembangan Bahasa Anak Usia Dini Di RT 04/RW 02 Desa Kajen Margoyoso Pati}

Terkait masalah ini, dapat dikatakan bahwa ketuju subjek utama dari penelitian ini mengatakan bahwa perkembangan bahasa anak di Rt 04/Rw 02 Desa kajen sebagian besar baik, lancar dan berkembang sesuai dengan perkembangan usianya. Hanya sajamereka sebagai orang tua perlu mengetahui dan sadar bahwa, mendidik anak harus dengan kesabaran dan ketelatenan. Secara garis besar mereka mengartikan bahwa perkembangan bahasa sangatlah penting untuk bersosialisasi atau berkomunikasi dengan orang, agar anak perkembangannya tidak tertinggal.Sejak kecil seharusnya dalam belajar berbicara anak memang perlu diajarkan seperti belajar mengucapkan kata, membangun kata-kata, dan membentuk kalimat M. Usman (2012). Mulai dari usia 4-5 tahun biasanya anak sudah banyak mengenal kata, berbicaranya pun juga sudah banyak. Pada tahapan ini anak sudah dapat membuat kalimat, seperti halnya telegram. Dilihat dari aspek pengembangan tata berbahasanya anak mampu memperpanjang 
kata menjadi kalimat seperti halnya, "Kamila sedang makan nasi goreng", "Ibu sedang mencuci pakaian",dan lain sebagainya. Sedangkan anak yang sudah berusia enam tahun sebagian tahapannya sudah mampu menggabungkan kalimat sederhana 4 dan kalimat kompleks (Ahmad Susanto, 2017).

Orang tua sebagai pemegang amanat dari Allah untuk mendidik dan menjaga anak dengan sebaik-baiknya memang harus berusaha menjadi pendidik yang terbaik untuk buah hatinya. Orang tua harus mengetahui bahwa sebenarnya pendidikan untuk anak bukan hanya dari sekolahan saja, tetapi orang tua juga berperan penting dalam mendidik anak dengan sabar dan ikhlas. Seperti halnya pendididkan berbahasa, orang tua juga harus sabar dalam melatih berbicara anak. Oleh sebab itu maka penting bagi orang tua untuk mengetahui hakikat berbahasa. Karena pemilihan bahasa yang tepat akan mengantarkan komunikasi yang baik, agar kedepannya perkembangan bahasa dapat diterapkan secara tepat kepada anak.

\section{Peran Orang Tua Dalam Meningkatkan Perilaku Berbicara Santun Anak Usia Dimi Di RT 04/RW 02 Desa Kajen}

Dari hasil analisis data, diketahui bahwa peran orang tua dalam meningkatkan perilaku berbicara santun kepada anak usia dini adalah sebagai berikut: Ketika mereka lahir kedunia, orang yang pertama mereka kenal adalah orang tua. Orang tua merupakan orang yang pertama kali dikenal anak. Orang tua mempunyai tanggung jawab atas pemeliharan dan pendidikan anak. Sehingga orang tua sanggat berperan penting dalam tumbuh kembangnya anak. Anak adalah cerminan dari orang tua, artinya perilaku atau tindakan anak tidak jauh menyimpang dari kebiasaan orang tuanya bertindak. Orang tua adalah maderasah yang pertama kali anak dapat sebelum mengenal guru disekolah.

Orang tua harus membiasakan anak dengan hal-hal terpuji sejak dini. Dengan memberikan pembiasaan akhlak terpuji dikehidupan sehari-hari, semisal denganmengajak anak untuk ikut sholat berjama'ah, kemudian memberikan contoh bersikap santun terhadap orang yang lebih tua darinya. Dengan cara kepada yang lebih tua menghormati dan yang muda menyayangi. Dan selalu menanamkan bersikap dan berbuat baik terhadap sesama (Dindin Jamaludin, 2013). Kemudian memberikan pendidikan pengembangan perilaku, yang dipelajari melalui pengalaman dengan lingkungan. Untuk perilaku sosial yang diberikan kepada anak sejak dini ini diarahkan untuk lebih mengajarkan saling berbagi kesesama, kemudian mengajarkan tolong menolong kesesama, dan sebisa mungkin orang tua juga memantau perkembangan lingkungan sekitar, karena lingkungan juga bisa mempengaruhi perkembangan baik buruknya perilaku anak (John W. Santrock, 2002). 
Selanjutnya pendidikan berbicara santun yang orang tua berikan adalah mendidik anak tentang bagaimana cara berbicara yang baik dan benar dapat diketahui bahwa karakter santun berkaitan dengan kehalusan bahasa. Kemudian orang tua menjelaskan kepada anak bahwa ketika berbicara dengan orang tua harus dengan bahasa yang baik, dan ketika berbicara anak selalu diingatkan untuk tidak menyela pembicaraan orang lain, kemudian ketika berbicara tidak menggunakan kata-kata yang kotor, kasar dan sombong (Sukini, 2016).

Dalam kaitannya dengan hal ini dapat dikatakan bahwa betapa berusahanya orang tua dalam mendidik anak-anaknya tentang perilaku berbicara santun sejak dini, mungkin dengan harapan agar anak kelak terbiasa dengan apa yang telah orang tua ajarkan. Pendidikan yang mereka ajarkan meliputiperilaku dan berbicara santun diusia dini, yaitu dengan mengenalkan pada anak tentang tingkah lakuseperti sikap peduli dan mau membantu sesama dengan sukarela tanpa timbal balik, berbicara santun berkaitan dengan kehalusan dalam bahasa.

Berdasarkan pemaparan diatas, peneliti dapat menjelaskan bahwa, semua peran orang tua dalam meningkatkan perilaku berbicara santun anak selama ini yang telah peneliti cros cek dari beberapa data yang ada mulai observasi dan wawancara yang menunjukkan bahwa peran orang tua dalam meningkatkan perilaku berbicara santun kepada anak usia dini (4-6 tahun) sebagian berjalan konsisten dan sebagian lagi belum berjalan konsisten.

\section{PENUTUP}

\section{Simpulan}

Berdasarkan hasil penelitian dan analisis data yang telah penulis paparkan pada bab sebelumnya mengenai Peran Orang Tua Dalam Meningkatkan Perilaku Berbicara Santun Anak Usia Dini Di Rt 04/Rw 02 Desa Kajen Margoyoso Pati, penyusun dapat menyimpulkan sebagai berikut:

1. Perkembangan Bahasa Anak Usia Dini Di Rt 04/Rw 02 Desa Kajen Margoyoso Pati. Berdasarkan hasil wawancara yang telah peneliti lakukan dengan 21 responden yang terdiri dari 7 responden sebagai Orang Tua Ananda, 7 responden sebagai Tetangga, dan 7 responden lagi sebagai Guru kelas Ananda ketika disekolahan. Dapat diketahui bahwa dari beberapa responden yang telah peneliti wawancarai diatas hampir semua menyatakan hal yang sama. Yaitu Perkembangan bahasa rata-rata anak yang berusia mulai dari 4-6 tahun perkembangannya lancar, kosakatanya bagus dan sudah banyak, dan juga sudah membentuk kalimat. Perkembangan bahasa perlu diajarkan kepada anak sejak dini, dengan tujuan agar anak lancar dalam berbahasa, dan berkembang sesuai dengan tahapan 
perkembangan usianya. Jadi Orang Tua juga harus mengetahui bahwa sebenarnya pendidikan untuk anak bukan hanya dari sekolahan saja, tetapi orang tua juga berperan penting dalam mendidik anak dengan sabar dan ikhlas. Seperti halnya pendididkan berbahasa, orang tua juga harus sabar dalam melatih berbicara anak. Oleh sebab itu maka penting bagi orang tua untuk mengetahui hakikat berbahasa. Karena pemilihan bahasa yang tepat akan mengantarkan komunikasi yang baik, agar kedepannya perkembangan bahasa dapat diterapkan secara tepat kepada anak.

2. Peran orang tua menjadi faktor penting dalam meningkatkan perilaku berbicara santun anak usia dini. Setiap perilaku, perkataan dan pembicaraan orang tua dan keluarga, akan menjadi contoh dan acuan bagi anak dalam bertingkah laku dan berbicara santun dalam kehidupan sehari-hari. Anak-anak yang tinggal dengan keluarga yang membesarkannya dengan tata cara berperilaku sopan santun, akan membentuk karakter dan sifat kebahasaannya. Demikian sebaliknya, anak yang dibesarkan dilingkungan yang kurang memahami pentingnya perilaku berbicara santun anak, akan cenderung bertingkah laku dan berbicara sembarangan.

\section{Saran}

Berdasarkan penelitian yang penulis lakukan dengan kerendahan hati ada beberapa saran yang ingin penulis sampaikan kepada para orang tua dalam mendidik anak:

1. Bagi orang tua diharapkan dapat membagi atau memanfaatkan waktunya untuk mendidik anak dengan sebaik-baiknya.

2. Bagi orang tua untuk bisa memberi teladan berperilaku santun yang baik kepada anakanaknya, supaya nanti anak dapat mengikuti dengan baik.

3. Di dalam mendidik anak sebaiknya orang tua tidak menggunakan kata-kata kasar, karena dengan tidak sengaja anak merekam kata-kata tersebut dan dapat diucapkannya dilain waktu.

4. Bagi peneliti lain, agar berkenan melakukan penelitian lanjutan. Karena peneliti menyadari bahwa hasil penelitian ini masih banyak kelemahan dari segi teori dan metodologinya.

\section{DAFTAR PUSTAKA}

Arikunto, Suharsini. (1998). Prosedur Penelitian "suatu pendekatan praktik”. Jakarta: Rineka Cipta. Artati, Budi. (2009). Sopan Berbahasa, Santun Berkata-kata. Klaten: PT Intan Pariwara. 
Brooks, Jane. (2011). The Process of Parenting. Yogyakarta: Pustaka Pelajar.

Hari Murdoko, Widijo. (2017). Parenting With Leadership "peran orangtua dalam mengoptimalkan dan memberdayakan potensi anak”. Jakarta: PT Elex Media Komputindo.

Iswara, Widya dkk. (2008). Pendekatan Jenis dan Metode Penelitian Pendidikan. Direktorat Tenaga Kependidikan Ditjen PMPK Depdiknas.

Jamaluddin, Dindin. (2013). Paradikma Pendidikan Anak Dalam Islam. Bandung: CV Pustaka Setia. Madyawati, Lilis. (2016). Strategi Pengembangan Bahasa Pada Anak. Jakarta: Prenadamedia Group. Priyanto, Rose Mini dkk. (2003). Perilaku Anak Usia Dini “Kasus dan Pemecahannya”. Jakarta: Kanisius.

Santrock W, John. (2002). Life Span Defelopment Perkembangan Masa Hidup. Jakarta: Erlangga.

Siregar, Alfitriani. (2018). Metode Pengajaran Bahasa Inggris Anak Usia Dini. Medan: Lembaga Penelitian dan Penulisan Ilmiyah Aqli.

Sugiyono. (2009). Metode Penelitian Pendidikan Pendekatan Kuantitatif, Kualitatif dan $R \&$ D, Cet. 7. Bandung: Alfabeta.

Sukini. (2016). Santun, (Yogyakarta: Relasi Inti Media.

Sumiyati. (2014). Konsep Pendidikan Anak Usia Dini dalam Islam. Yogyakarta: Cakrawala Institute. Susanto, Ahmad. (2011). Perkembangan Anak Usia Dini "Pengantar Dalam Berbagai Aspeknya". Jakarta: Kencana.

Suyadi. (2014). Teori Pembelajaran Anak Usia Dini “Dalam Kajian Neurosains”. Bandung: PT Remaja Rosdakarya.

Ulfah, Maulidya dan Suyadi. (2013). Konsep Dasar PAUD. Bandung: PT Remaja Rosdakarya.

Usman, Muhammad. (2012). Perkembangan Bahasa dalam Bermain dan Permainan "Untuk Pendidikan Anak Usia Dini”. Yogyakarta: CV Budi Utama.

Wulan, Ratna. (2011). Mengasah Kecerdasan Pada Anak, "bayi-prasekolah”. Yogyakarta: Pustaka Pelajar. 